\title{
Medicinal plants used for diarrhoea treatment in sheep and goats among smallholders in farm settlements of Ogun state, Nigeria

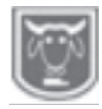 \\ Fasae, O. A. and Adenuga, A. J. \\ Department of Animal Production and Health, \\ Abstract Federal University of Agriculture, P.M.B.2240, Abeokuta, Nigeria.
}

The use of traditional remedies in the treatment of diarrhoea in ruminants is a common form of therapy among poor resource smallholder farmers in Nigeria with restricted access to veterinary healthcare services. The medicinal plants of antidiarrheal importance in smallholder sheep and goat production systems were studied in farm settlements namely Ado-Odo, Ikenne and Ibiade, located in Ogun state, Nigeria. Techniques including interviews, observations and guided field walks were used to collect data from 150 farmers across the farm settlements. Results showed that all respondents owned either sheep or goats with goats more preferred, while diarrhea was also observed to be a major disease problem in goats compared to sheep. About $92 \%$ of the farmers admitted using anti-diarrhoea herbs and about $80 \%$ agreed to their effectiveness in the treatment of diarrhoea in sheep and goats. The study identified 11 plant species used to treat diarrhoea with varied recipe and the route of administration was orally. Less than $12 \%$ of these plant parts were administered solely, preparing as a single-component while the majority of the identified plants were used in combination with other plant parts. Phytochemical components were analyzed for tannin, saponin, flavonoid and alkaloid which were observed in different plant parts showing their potential as antidiarrheal agents.The usage of these plants could therefore be an indispensable component of traditional medicine practice which can serve as safe alternative and complementary medicines to various allopathic drugs that could help safeguard health and obtain optimum production from animals.

Keywords: Sheep, goats, diarrhoea, medicinal plants, phytochemical, Ogun state Nigeria

\section{Introduction}

Sheep and goats are the predominant domestic ruminants, widely distributed in the rural and peri-urban areas of Nigeria. They play a valuable role in sustainable agricultural systems and are particularly useful in converting vast renewable resources from rangeland, pasture and crop residues into food edible for humans (Adu et al., 1996; Hirpa and Abebe, 2008). However, their productivity is hampered among other factors by diseases that present diarrhoea as a symptom. Diarrhoea is one of the most common and costly condition affecting livestock with clinical signs of gastrointestinal disorders caused by both infectious and non-infectious agents (Randolph et al., 2007) and these probably is caused as a result of characterised high rainfall, humidity and heat in the region that provide ideal conditions for disease-causing organisms, thereby impeding the productivity of sheep and goats by various health constraints among which diarrhoea have been found to have higher prevalence.

Back to antiquity, rural farmers have developed indigenous methods or technologies for coping with the constraints using natural herbs primitively as remedies. Preparations derived from medicinal plants were the original therapeutic interventions used by man to control diseases, both within humans and livestock with exhaustive lists of plants having medicinal properties been documented around the world 


\section{Medicinal plants used for diarrhoea treatment in sheep and goats Ogun state, Nigeria}

(Athanasiadou et al., 2007). Medicinal plants though not universally recognised as a valid method of disease control in animals (Matekaire and Bwakura, 2004) are relatively simpler to prepare and administer and have been known to provide low cost animal health care alternatives in rural communities, due to their important antimicrobial principles, phytoconstituents and therapeutic potentials.

With the increasing awareness of the potential of natural products using medicinal plants in the treatment of diseases in animal healthcare systems, this study identifies medicinal plants in treating diarrhoea as an indispensable component of traditional medicine practice in enhancing sheep and goats productivity in the study areas.

\section{Materials and methods}

The study was carried out in farm settlements located in three senatorial districts of Ogun State, Nigeria namely Ado-Odo, Ikenne, and Ibiade farm settlements, where the rearing of sheep and goats is common among the settlers. The region is located around latitude $6^{\circ} 47^{\circ}$ and longitude $3^{\circ} 58^{\circ} \mathrm{E}$ in South Western Nigeria. The area experiences humid tropical climate which is characterised by alternate wet and dry season seasons like the rest of Nigeria. The region on annual basis experiences the rainy season (AprilOctober) and hot-dry season (November March). Rainfall is generally heavy with peaks occurring in July and September coupled with high temperature and high relative humidity. The mean annual rainfall is between $1575 \mathrm{~mm}$ and $2340 \mathrm{~mm}$ (Aiyelokun and Odekoya, 2016). Crop production and livestock are the major sources of cash income generation in these settlements with a variety of livestock types and species including sheep, goat, pigs, and chickens.

Techniques including personal interviews, observations and guided field information were used for data collection from sheep and goat rearers in the study area. To give some structure to the interviews and information garnered, questions were specifically asked around diarrhoea outbreak and general conditions of the animals. Structured questionnaires were used to collect data from 50 farmers from each of the farm settlements, making altogether 150 farmers. In addition, respondents and other settlers who had knowledge on herbal medicine were selected for a focus group discussion in order to validate the responses from the interview. Major questions on the identified plants were asked such as parts of plant used, preparation method and mode of administration for the treatment of diarrhoea. The phytochemical screening of the plant parts for alkaloids, saponins, flavonoids and tannins was carried out according to the procedures described by Trease and Evans (1989). The data analysis was done using Microsoft Excel package and summarised using descriptive statistics.

\section{Results and discussion}

All respondents owned either sheep or goats and the farmers' reasons for keeping these animals were for multiple purposes which are similar to reasons for keeping these animals in most sub-Saharan Africa countries (Masika and Mafu, 2004). The preference of ruminant type across locations (Figure 1) showed that goats were more preferred to sheep in the study areas and this is similar to the reports on the higher mean herd size of goats per household compared to sheep flock size in Nigeria (Gefu et al., 1994; Anaeto et al., 2009). Results across the study areas revealed that diarrhoea is a major disease 


\section{Fasae and Adenuga}

problem in sheep and goats, being a major clinical sign of many diseases. Randolph et al. (2007) noted that diarrhoea is not intrinsically considered a disease, but rather a clinical sign of other health problems in ruminants caused by infectious and non infectious agents; and it is the most common and costly condition affecting livestock. Over the years, diarrhoea among other diseases have been found to be responsible for over $83.3 \%$ of the total cause of death in goats in Nigeria (Otesile et al, 1983; Obudu et al, 1995).

In this study, goats generally were more affected with diarrhoea than sheep (Figure

2 ) which is at variance with earlier reports

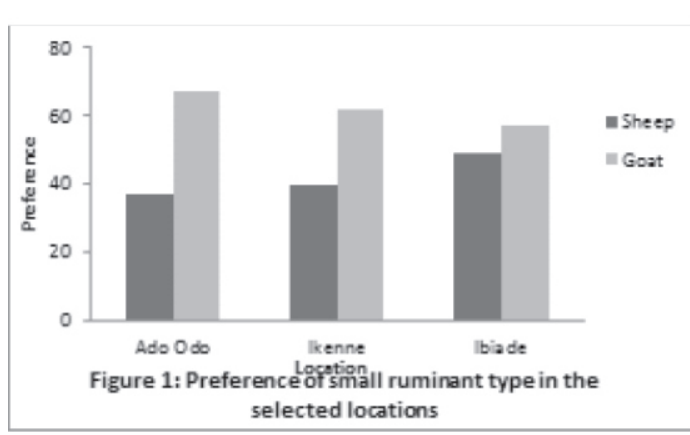

The level of usage and the effectiveness of medicinal plants in the treatment of diarrhoea in sheep and goats across the study areas are shown in Table 1. More than $92 \%$ of the farmers admitted using antidiarrhoea herbs to treat their animals, with more than $80 \%$ agreed to their effectiveness in the treatment of diarrhoea. This could be attributed to the preference for the use of locally and readily available herbal remedies compared to the expensive and erratic supply of conventional medicines that are unavailable around the settlements. These plants were perceived by the respondents as cheap, usually at low cost and do not have side effects on their livestock. Gueye (1999) documented the of more occurrence of diarrhoea in sheep than in goats (Unigwe et al., 2016). The variation could be attributed to the environment and management of animals. Dela-Fuente et al., (1997) attributed the prevalence of diarrhoea among other diseases in small ruminants on the animal's environment. Mahmood et al, (2014) recorded a significant association in goats of a number of cases of diarrhoea with the environmental temperature, with the highest prevalence in the temperature range from $25-30{ }^{\circ} \mathrm{C}$, which turned out to be an ideal environment temperature for the occurrence of diarrhoea.

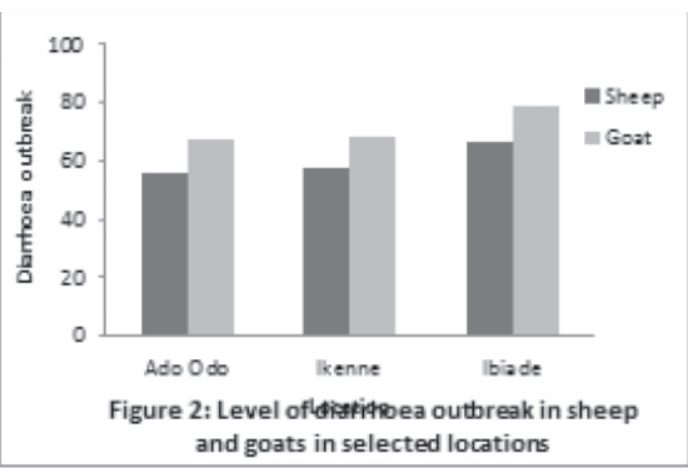

use of medicinal herbs is the only option for most resource-limited farmers in Africa because of lack of veterinarians in the rural areas.

Although, orthodox treatments are certainly indispensable in cases such as epidemics of contagious diseases, but for common ailments like diarrhoea among other diseases, the use of herbal medicine have been found to function effectively (Martin et al., 2001).

The reason however, given by the few respondents that indicated their lack of interest in the use of herbal remedies to treat diarrhoea was adduced to the fact that the indigenous knowledge of using herbs in the treatment of animal diseases is being 


\section{Medicinal plants used for diarrhoea treatment in sheep and goats Ogun state, Nigeria}

outdated and socially inferior. Some further attested of its inability to cure some diseases as well as not having preservation methods which could keep the active ingredients thus necessitated collection of fresh materials whenever it was needed. Also, the fact that the ideal dosage or toxicity of these herbs cannot be measured has kept some respondents from its usage. Similar findings were recorded by Minja and Allport (2000).

Moreover, friends and neighbours were found to play a major role in the dissemination of knowledge in the usage of these herbs, indicating that there was a lot of sharing of knowledge between the rearers. Other sources of herbal knowledge transfer were through oral conversation from the daily practice of livestock management with very little obtained from the training and extension of local livestock officers. Also, few settlers had learnt about herbal remedies from across generations and religious leaders.

The list of eleven (11) identified plants, their botanical, common and local names and the plant parts used for the treatment of diarrhoea in sheep and goats in the study areas are presented in Table 2. Seeds, fruits, stem, bark, leaves, roots, rhizomes and bulbs were the common plant parts used for diarrhoea treatment. Few of these plant parts were used solely, preparing as a singlecomponent while the majority of the identified plants involved the combination of more than one medicinal plant or in combination with other plant parts.

The variations on these herbal combinations were found to be numerous and highly varied across plant species while the route of administration was orally. Yigezu et al. (2014) had earlier noted that oral routes are considered as one of the most effective methods of herbal administration due to their immediate physiological reaction with the pathogens and escalating the healing capacity of the medicine. This is consistent with earlier studies of Kebu et al. (2004) that greater than half of herbal remedies studied in disease treatment were administered orally.

The phytochemical screening of these plant parts showed the presence of active pharmacological components such as tannins, saponins, flavonoids and alkaloids, which are known to be biologically active and have been shown to possess anti-diarrheal properties (Longanga et al., 2000; Edeoga et al., 2001). Plants produce a diverse array of secondary metabolites with many functions, such as defence against diseases and parasites

Table 1: Level of usage of medicinal plants for the treatment of diarrhoea in sheep and goats across farm settlements

\begin{tabular}{lcccccc}
\hline \multirow{2}{*}{\multicolumn{1}{c}{ Parameters }} & \multicolumn{5}{c}{ Farm settlements } \\
\cline { 2 - 7 } & \multicolumn{2}{c}{ Ado Odo $(\mathbf{n = 5 0 )}$} & \multicolumn{2}{c}{ Ikenne $(\mathbf{n = 5 0})$} & \multicolumn{2}{c}{ Ibiade (n=50) } \\
\cline { 2 - 7 } & Frequency & $\mathbf{\%}$ & Frequency & $\mathbf{\%}$ & Frequency & $\mathbf{\%}$ \\
\hline Frequency of usage & 47 & 94 & 48 & 96 & 46 & 92 \\
Herbs effectiveness & 40 & 80 & 42 & 84 & 45 & 90 \\
Knowledge source & & & & & & \\
Religious leader & 4 & 8 & 4 & 8 & 5 & 10 \\
Friend/Neighbour & 19 & 38 & 18 & 36 & 22 & 44 \\
Oral conversation & 17 & 34 & 21 & 42 & 19 & 38 \\
Generational history & 9 & 18 & 7 & 14 & 3 & 6 \\
Local extension officers & 1 & 2 & - & - & 1 & 2 \\
\hline
\end{tabular}




\section{Fasae and Adenuga}

Table 2: Medicinal plants and phytochemical properties (PP) used for treatm ent of diarrh oea in sheep and goats

\begin{tabular}{|c|c|c|c|c|c|c|}
\hline \multirow[t]{2}{*}{ Names and plant part used } & \multicolumn{4}{|c|}{ PP } & \multirow[t]{2}{*}{ Recipe } & \multirow[t]{2}{*}{ R. A } \\
\hline & $\mathbf{A}$ & $\mathbf{S}$ & $\mathbf{F}$ & $\mathbf{T}$ & & \\
\hline $\begin{array}{l}\text { Botanical : Allium sativa } \\
\text { Common: Garlic } \\
\text { Indigenous: Ayuu } \\
\text { Part used: Bulb }\end{array}$ & + & + & + & + & Decoction & Oral \\
\hline $\begin{array}{l}\text { Botanical : Azadirachtaindica } \\
\text { Common: Neem tree } \\
\text { Indigenous: Dongoyaro } \\
\text { Part used: Stem bark and leaf }\end{array}$ & + & + & + & + & $\begin{array}{l}\text { Soak fresh or dried } \\
\text { pounded bark of neem } \\
\text { in boiled water }\end{array}$ & Oral \\
\hline $\begin{array}{l}\text { Botanical : Carica papaya } \\
\text { Common: Pawpaw } \\
\text { Indigenous: Ibepe } \\
\text { Part used: Fruit }\end{array}$ & + & + & + & + & $\begin{array}{l}\text { Prepare a concoction by } \\
\text { boiling grated papaya } \\
\text { fruits in water }\end{array}$ & Oral \\
\hline $\begin{array}{l}\text { Botanical:Chenopodiumambrosi } \\
\text { odes } \\
\text { Common: Worm wood } \\
\text { Indigenous: Arunpale } \\
\text { Part used: Root and leaf }\end{array}$ & + & + & + & + & $\begin{array}{l}\text { Decoction of dried } \\
\text { leaves }\end{array}$ & Oral \\
\hline $\begin{array}{l}\text { Botanical : Citrus aurantifolia } \\
\text { Common: Lime } \\
\text { Indigenous: Osanwewe } \\
\text { Part used: Fruit and leaf }\end{array}$ & + & + & + & + & $\begin{array}{l}\text { Extract the fruit juice } \\
\text { and mixed with sugar to } \\
\text { make paste }\end{array}$ & Oral \\
\hline $\begin{array}{l}\text { Botanical : Elaeisguineensis } \\
\text { Common: Oil palm } \\
\text { Indigenous: Ope } \\
\text { Part used: Fruit extract }\end{array}$ & + & + & + & + & $\begin{array}{l}\text { Mix oil extract with } \\
\text { little salt }\end{array}$ & Oral \\
\hline $\begin{array}{l}\text { Botanical : Ocimumgratissimum } \\
\text { Common: African basil } \\
\text { Indigenous: Efinrin } \\
\text { Part used: Leaf }\end{array}$ & + & + & + & + & $\begin{array}{l}\text { Squeezed leaves with } \\
\text { Nicotianatabacum and } \\
\text { administer juice }\end{array}$ & Oral \\
\hline $\begin{array}{l}\text { Botanical : Lagenariabreviflorus } \\
\text { Common: Wild colocynth } \\
\text { Indigenous: Tagiri } \\
\text { Part used: Fruit }\end{array}$ & + & + & + & + & Decoction of fruits & Oral \\
\hline $\begin{array}{l}\text { Botanical : Mangiferaindica } \\
\text { Common: Mango } \\
\text { Indigenous: Mangoro } \\
\text { Part used: Stem bark }\end{array}$ & + & + & + & + & $\begin{array}{l}\text { Bark is soaked for } 24 \\
\text { hours and the water } \\
\text { extract is used }\end{array}$ & Oral \\
\hline $\begin{array}{l}\text { Botanical : Zea mays } \\
\text { Common: Maize } \\
\text { Indigenous: Agbado/Ooka } \\
\text { Part used: Seeds }\end{array}$ & + & - & + & - & Seeds roasted & Oral \\
\hline $\begin{array}{l}\text { Botanical : Zingiberofficinale } \\
\text { Common: Ginger } \\
\text { Indigenous: Ataale }\end{array}$ & + & + & + & - & $\begin{array}{l}\text { Rhizome with sugar are } \\
\text { grinded to make fine } \\
\text { powder }\end{array}$ & Oral \\
\hline
\end{tabular}

Part used: Rhizome

$\mathrm{PP}=$ Phytochemical properties, $\mathbf{A}=$ Alkaloid, $\mathbf{S}=$ Sapon in, $\mathbf{F}=$ Flavonoid, $\mathbf{T}=$ Tannin, $\mathbf{R}$. A. $=$ Route of Administration; $+=$ Present, $-=$ Absent 


\section{Medicinal plants used for diarrhoea treatment in sheep and goats Ogun state, Nigeria}

(Pieters and Vlietinck, 2005). These chemicals from plants may possess complex chemical structures that are not available in synthetic compound libraries.

Reports have shown that the anti-diarrhoea effects of many medicinal plants have been attributed to their rich flavonoid and tannin contents as the potential use of these plant extracts as therapeutic agents could be adduced to the presence of active principles or chemical compounds in their extracts (Abdullahi et al., 2001; Oyewole, 2003). Phyto-therapeutically tannin-containing plants have been used to treat nonspecific diarrhoea and inflammatory diseases and studies with ruminants have also demonstrated that the denaturing properties of tannins can possibly be used to improve protein supply to the small intestine (Westendarp, 2006)

In recent times, phytochemicals are promoted for the prevention and treatment of many health conditions and their presence provide scientific explanation of the long use, recommendation and activities of some of these plants as anti-diarrhoea among other ailments in livestock (Burkill, 1994). This justified the use of these herbs in traditional medicine among the farm settlers as a natural and effective remedy for treating diarrhoea in sheep and goats in this study. This also affirms the findings of Orwa et al. (2009) that many plants leaves, bark, pods and roots have been found to possess astringent properties and are used medicinally for a wide variety of ailments including diarrhoea.

The mode of preparation and effect of combination of indigenous herbs for the treatment of diarrhoea in sheep and goats across the various settlements are shown in Table 3, with the mode of preparation of the remedies being basically in the form of extractions, decoctions and concoctions. Few of the herbal preparations were applied in single combination why majority were applied through multiple combination with other herbs. The mode of preparation through multiple combination of herbs are based on the local belief that synergistic actions between the plants would increase the benefit to the animal as herbal remedies generally contained materials from more than one plant species. This corroborates the observation of Ofukwu (2008) and Tabuti et al. (2010) in researches on medicinal plants used by traditional medicine practitioners in the treatment of various ailments of humans and animals in Nigeria and Uganda, respectively.

Table 3: Mode of preparation and effect of combination of medicinal plants for the treatment of diarrhoea in sheep and goats

\begin{tabular}{|c|c|c|c|c|c|c|}
\hline \multirow[t]{3}{*}{ Parameters } & \multicolumn{6}{|c|}{ Farm settlements } \\
\hline & \multicolumn{2}{|c|}{ Ado Odo $(n=50)$} & \multicolumn{2}{|c|}{ Ikenne $(\mathrm{n}=50)$} & \multicolumn{2}{|c|}{ Ibiade $(\mathrm{n}=\mathbf{5 0})$} \\
\hline & Frequency & $\%$ & Frequency & $\%$ & Frequency & $\%$ \\
\hline \multicolumn{7}{|l|}{ Mode of preparation } \\
\hline Decoction & 14 & 28 & 13 & 26 & 17 & 34 \\
\hline Concoction & 7 & 14 & 5 & 10 & 5 & 10 \\
\hline Extraction & 29 & 58 & 32 & 64 & 28 & 56 \\
\hline \multicolumn{7}{|l|}{$\underline{\text { Combination effects }}$} \\
\hline Multiple combination & 43 & 88 & 49 & 98 & 47 & 96 \\
\hline Single combination & 7 & 12 & 1 & 2 & 3 & 4 \\
\hline
\end{tabular}




\section{Conclusion}

Based on the study, the use of herbal remedies in the treatment of diarrhoea in sheep and goats is a common practice basically owing to low cost, convenience and ease of administration. The identified plants parts have been found to exhibit antidiarrhoea activity which can be used as natural agents for the treatment of diarrhoea in sheep and goats. The usage of these medicinal plants could therefore be an indispensable component of traditional medicine practice in the treatment of diarrhoea, serving as a safe alternative and complementary medicine to the more expensive various allopathic drugs. Further studies are needed to evaluate not only the bioactivity but also the safety of these plant treatments if their use is to be promoted and potentially developed for commercial purposes.

\section{References}

Abdullahi, A. L., Agbo, M. O., Gamanial, K. S. and Wambebe, C. 2001.Anti-diarrheoa activity of the aqueous extract of Terminalia avicenniodes root. Phytotherapy Research, 19:431-434.

Adu, I.F., Aina, A.B.J, and Okeleye, K.A. 1996. On- farm establishment and productivity of Gmelina and Gliricidia as browse for goats. Nigerian Journal of Animal Production, 23 (1): 47 - 52.

Aiyelokun O. and Odekoya O. 2016. Analysis of trend and variability of atmospheric temperature in IjebuOde, Southwest Nigeria. International Research Journal of Agricultural Science and Soil Science 6(2): 25-31.

Anaeto M., Tayo G. O., Chioma, G. O., Ajao A. O. and Peters T. A. 2009. Health and nutrition practices among smallholder sheep and goat farmers in Ogun State Nigeria.Livestock Research for Rural Development 21 (11).

Athanasiadou, S., Githiori, J. and Kyriazakis, I. 2007. Medicinal plants for helminth parasite control: facts and fiction. Animal 1(9):1392-1400.

Burkill, H. M., 1994. The Useful Plants of West Tropical Africa, vol.2, Families E-I, Royal Botanic Garden, Kew, pp. 605.

Edeoga, H. O. and Eriata, D. O. 2001.Alkaloid, tannin and saponin contents of some medicinal plants. Journal of Medicinal Aromatic Plant Sciences, 23: 344-349.

Gefu, J. O., Adu I. F., Alawa C. B. I. and Magaji S. O. 1994. Characteristics of smallholder sheep and goat management practices in South East Nigeria: Observation from Anambra State. Nigerian Journal of Animal Production 21(1\&2):127-134.

Gueye, E. F. 1999. 'Ethnoveterinary medicine against poultry diseases in African villages', World's Poultry Science Journal 55(2): 187-198.

Hirpa, A. and Abebe, G. 2008. Economic Importance of Sheep and Goats. In: Sheep and Goat Production Handbook for Ethiopia, Addis Ababa, pp. 1-4.

Kebu B., Ensermu K. and Zemede A. 2004.Indigenous medicinal utilization, management and threats in Fentale area, Eastern Shewa, Ethiopia. Ethiop. J. Biol. Sci.,3(1):37-58.

Unigwe, C. R., Ogbu, U. M., Balogun, F. A., Orakwue, O. K., Nwufoh, O. C. and Nwachukwu, B. C. 2016. 
Prevalence of Small Ruminant Diseases/Disorders at Mokola Veterinary Hospital, Ibadan, Nigerian Journal of Biology, Agriculture and Healthcare 6, (1):

Longanga $O$. A, Vercruysse A. and Foriers A. 2000. Contribution to the ethnobotanical, phytochemical and pharmacological studies of traditionally used medicinal plant in the treatment of dysentery and diarrhoea in Lomela area, Democratic Republic of Congo .J.Ethnopharmacol. 71(3): 411423.

Mahmood, A. K., Khan, M. S. , Khan M. A. and Bilal M. 2014. Prevalence of Salmonella in diarrheic adult goats in field conditions, J. Anim. Plant Sci. 24(1): 98.

Martin, M., Mathias, E. and McCorkle, C. M. 2001.Ethnoveterinary Medicine: An Annotated Bibliography of Community Animal Healthcare. ITDG Publishing, London, UK.

Masika, P. and Mafu, J. V. 2004. 'Aspects of goat farming in the communal farming systems of the central Eastern Cape, South Africa', Small Ruminant Research 52(1): 161-164.

Matekaire $T$ and Bwakura T. M. 2004. Ethnoveterinary medicine: A potential alternative to orthodox animal health delivery in Zimbabwe. International Journal Applied Research in Veterinary Medicine 2 (4): 269-273.

Minja, M. M. J. and Allpart R. D. 2000.Ethnoveterinary practised by Maasai in Simanjiro District Northern Tanzania

Obudu C . E., Adedeji O. S. and Otesile E. B. 1995.Incidence and causes of mortality in goats on the University of Ibadan Teaching and Research Farm. A retrospective study.Israel Journal of Veterinary Research 50: 29-83.

Ofukwu R. A., Ayoola A. and Akuwobu C. A. 2008. Medicinal plants used in treatment of tuberculosis in humans and animals in Idoma tribe of North Central Nigeria, Nigerian Vet. Journal, 29 (2): 2530.

Oni O. O. 2002. Breeds and genetic improvement of small ruminants.A publication on sheep and goats, National Animal Production Research Institute.Ahmadu Bello University Shika, Zaria, Nigeria, Sheref Salam Press, pp. 3-4.

Orwa, C., Mutua, A., Kindt, R., Jamnadass, R. and Anthony, S. 2009. Agroforestree Database: a tree reference and selection guide version 4.0. World Agroforestry Centre, Kenya.

Otesile E. B., Kasali O. B. and Nzekwu C. K. N. 1983. Mortalities in goats on the University of Ibadan Teaching and Research Farm. Bulletin of Animal Health and Production in Africa, 31:282-284.

Oyewole, J. A. O. 2003. Evaluation of the anti -inflammatory properties of Sclerocaryabirrea (Anacardiaceae) stem-bark extract i n rats. Journal of Ethnopharmacology, 85:217-220.

Pieters, L. and Vlietinck, A. J. 2005. Bioguided is olation of pharmacologically active plant components, still a valuable strategy for the finding of new lead compounds. Journal of Ethnopharmacology, 100, 57-60.

Randolph T. F., Schelling E., Grace D., 


\section{Fasae and Adenuga}

Nicholson C. F., Leroy J. L., Cole D. C., Demment M. W., Omore A., Zinsstag T. and Ruel M. 2007. Invited interview: Role of livestock in human nutrition and health for poverty reduction in developing countries.Journal of Animal Science, 85:2788-2800.

Tabuti J. R. S., Collins B., Kukunda C. B., Paul J. and Waako P. J. 2010. Medicinal plants used by traditional medicine practitioners in the treatment of tuberculosis and related ailments in Uganda. Journal of Ethnopharmacology, 127:130-136.

Trease G. E. and Evans W. C. 1989. P harm a cog nos y. 13 th Edition.BailliereTindall Ltd., London, pp. 350-389.
Westendarp H. 2006. Effects of tannins in a $n$ i $m$ a 1 nutrition,DtschTierarztlWochensch $r, 113(7): 264-268$.

Yigezu Y., Haile, D. B. and Ayen, W. Y. 2014. "Ethno veterinary medicines in four districts of Jimma zone, Ethiopia: cross sectional survey for plant species and mode of use," BMC Veterinary Research, vol. 10, article 76, 2014.

Received: $19^{\text {th }}$ March, 2017

Accepted: $21^{\text {st }}$ June, 2017 